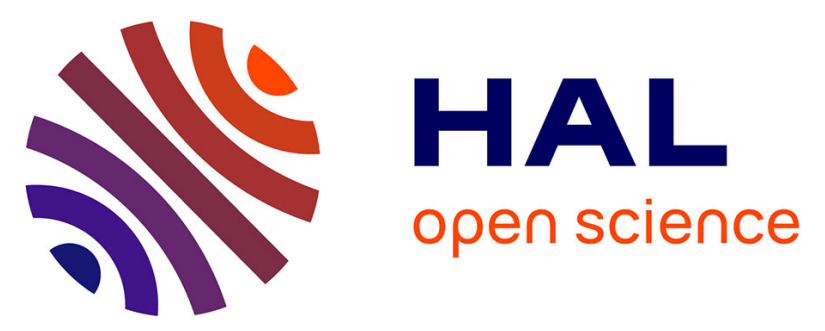

\title{
CO2 sequestration and simultaneous zeolite production by carbonation of coal fly ash: Impact on the trapping of toxic elements
}

Luis Monasterio-Guillot, Pedro Alvarez-Lloret, Aurelia Ibañez-Velasco, Alejandro Fernandez-Martinez, Encarnación Ruiz-Agudo, Carlos Rodriguez-Navarro

\section{To cite this version:}

Luis Monasterio-Guillot, Pedro Alvarez-Lloret, Aurelia Ibañez-Velasco, Alejandro FernandezMartinez, Encarnación Ruiz-Agudo, et al.. CO2 sequestration and simultaneous zeolite production by carbonation of coal fly ash: Impact on the trapping of toxic elements. Journal of CO2 Utilization, 2020, 40, pp.101263. 10.1016/j.jcou.2020.101263 . hal-03043981

\section{HAL Id: hal-03043981 \\ https://hal.science/hal-03043981}

Submitted on 5 Jan 2021

HAL is a multi-disciplinary open access archive for the deposit and dissemination of scientific research documents, whether they are published or not. The documents may come from teaching and research institutions in France or abroad, or from public or private research centers.
L'archive ouverte pluridisciplinaire HAL, est destinée au dépôt et à la diffusion de documents scientifiques de niveau recherche, publiés ou non, émanant des établissements d'enseignement et de recherche français ou étrangers, des laboratoires publics ou privés. 
$1 \mathrm{CO}_{2}$ sequestration with simultaneous zeolite production and toxic elements

\section{2 trapping by carbonation of Coal Fly Ash}

3 Monasterio-Guillot, L. ${ }^{{ }^{*}}$, Alvarez-Lloret, P. ${ }^{2}$. Ibañez-Velasco, A. ${ }^{1}$, Fernandez-Martinez, A. ${ }^{3}$,

4 Ruiz-Agudo, E. ${ }^{1}$ and Rodriguez-Navarro, C. ${ }^{1}$

51 Department of Mineralogy and Petrology, Univ. of Granada, , 18071, Granada, Spain

62 Department of Geology, Univ. of Oviedo, 33005, Oviedo, Spain

73 Univ. Grenoble Alpes, Univ. Savoie Mont Blanc, CNRS, IRD, IFSTTAR, ISTerre, 38000

8 Grenoble, France

$9 *$ corresponding author: luismonasterio@ugr.es

\section{ABSTRACT}

12 Coal-fired power plants are main contributors to atmospheric $\mathrm{CO}_{2}$ emissions. They also produce

13 huge amounts of coal fly ash (CFA) waste, which is typically landfilled, posing significant

14 environmental risks due to its high content of potentially toxic elements (PTE). However, CFA

15 is an alkaline aluminosilicate-rich waste, which offers the possibility of $\mathrm{CO}_{2}$ mineral capture and

16 the production of economically-relevant mineral by-products such as zeolites. Yet, the combined

17 carbonation and zeolite production from CFA resulting in PTE trapping has never been

18 explored. Here we show that under mild hydrothermal conditions $\left(150^{\circ} \mathrm{C}\right)$ and depending of

19 process parameters such as $\mathrm{pH}$ and background alkali metal ion in alkaline (bi)carbonate

20 solutions, a carbonation efficiency of up to $79 \%$, with a net $\mathrm{CO}_{2}$ mineral capture of $0.045 \mathrm{~g} / \mathrm{kg}$

21 CFA can be achieved, even when using a low $\mathrm{Ca}$ and $\mathrm{Mg}(3.72 \mathrm{wt} \% \mathrm{CaO}, 1.74 \mathrm{wt} \% \mathrm{MgO})$

22 Class F fly ash. Moreover, amorphous zeolitic precursors and different crystalline zeolites (yield 
23 up to $60 \mathrm{wt} \%$ ) are simultaneously obtained, and PTE in CFA are effectively trapped into the

24 newly formed calcite, zeolitic precursors, and zeolite phases. These results have important

25 implications for carbon capture and storage, as well as for the safe reutilization and disposal of

26 CFA waste.

\section{INTRODUCTION}

Coal combustion is the second energy source most used worldwide, with a consumption

29 of 1.4 billion tonnes in $2018,4 \%$ higher than the previous year. ${ }^{1}$ It accounts for more than $30 \%$

30 of the global yearly anthropogenic $\mathrm{CO}_{2}$ emissions, being a key contributor to climate warming

31 and the associated changes in the oceans and atmosphere equilibria. ${ }^{1}$ Coal firing also produces

32 huge amounts of coal combustion waste products (CCP), which include coal fly ash, CFA ( 70

$33 \%$ of CCP), ${ }^{2}$ bottom ash, boiler slag, and fluidized bed combustion wastes. ${ }^{3,4}$ Global CFA

34 generation was over 700 million tons $(\mathrm{Mt})$ per year in $2012^{3,4}$, and this figure kept growing in

35 recent years ${ }^{5}$. Management of the huge amounts of CFA waste produced globally is a significant

36 problem, with important economic, health, and environmental implications. ${ }^{4}$ Worldwide, $\sim 70 \%$

37 of CFA is disposed of in ash ponds or landfills, the rest being recycled for several applications. ${ }^{3}$

38 Only in the U.S., 34 Mt of CFA were generated in $2016,{ }^{1,6}$ of which 20 Mt were used mainly as

39 a construction material due to its pozzolanic properties (e.g., concrete products, blended

40 cements, road base) or in mining applications; still, 14 Mt of CFA were discarded and subjected

41 to ponding or landfilling. ${ }^{7}$ In addition to the huge area needed to store or dispose of CFA, ${ }^{8}$ this

42 waste includes a significant amount of potentially toxic trace elements (PTE) ${ }^{9-11}$ which may 
43 limit its recycling capability and make CFA spilling or leaching a hazard resulting in

44 contamination of soils, water bodies and groundwater. ${ }^{12-16}$

46 synthesis of zeolites ${ }^{17-19}$, which are microporous crystalline aluminosilicates formed by corner-

47 sharing tetrahedral groups conforming voids and channels that allow the adsorption of gases,

48 metal ions and organic molecules. ${ }^{9,18,20-22}$ Due to their pore characteristics and high ion exchange

49 capacity, ${ }^{23}$ CFA-derived zeolites are employed for $\mathrm{CO}_{2}$ (and other pollutant gases) capture,

50 removal of toxic metals, water decontamination, and soil improvement. ${ }^{18,19,24-26}$ CFA-derived

51 zeolite synthesis has focused on the use of $\mathrm{NaOH}$ (and $\mathrm{KOH}$ ) for hydrothermal, alkali fusion, or

52 microwave-assisted production. ${ }^{19} \mathrm{~A}$ few works explored the use of alkali carbonate activators

53 for hydrothermal zeolite synthesis $\left(120^{\circ} \mathrm{C}\right)$, reporting a limited zeolite yield but, interestingly,

54 resulting in calcium carbonate precipitation..$^{20}$ The latter suggests that the combined carbonation

55 and zeolite synthesis using CFA is feasible. Although several works have shown that zeolites

56 formed after CFA can be used to capture PTE ${ }^{18,19}$, no study has evaluated the actual trapping of

57 PTE present in the CFA used for zeolite synthesis; and (ii) to a lesser extent, CFA has been used

58 for carbon capture and storage (CCS) via accelerated mineral carbonation. ${ }^{27-33}$ Despite the

59 limited foreseen contribution of CFA to mineral carbon sequestration $\left(\sim 7.6 \mathrm{Mt} / \mathrm{CO}_{2} / \mathrm{y}\right),{ }^{34}$ its use

60 for carbon capture, utilization and storage (CCUS) must be considered as it could contribute to

61 the reduction of the $\mathrm{C}$ footprint of coal-fired power plants, ${ }^{1,6,30}$ result in the production of

62 economically-valuable by-products such as carbonates and zeolites, and in a reduction of the 
63 potential leaching of PTE during CFA disposal. ${ }^{30}$ Previous works have evaluated the

64 carbonation efficiency (CE) and net $\mathrm{CO}_{2}$ capture of CFA from different sources and

65 compositions under a range of process conditions (e.g., direct and indirect carbonation, dry vs.

66 wet processes, $\mathrm{pH}, T$, solid/solution ratios, aqueous solution composition, $\left.p \mathrm{CO}_{2}\right){ }^{3,35}$ These

67 studies show that $\mathrm{CE}$ values are typically $<<80 \%{ }^{5,36}$, and the net $\mathrm{CO}_{2}$ capture can be as low as

$68 \sim 8 \mathrm{~kg}$ per ton of CFA. With a few exceptions (CFA with $\mathrm{CaO}+\mathrm{MgO}>20 \mathrm{wt} \%{ }^{2,11,33}$ ), the

69 average $\mathrm{CaO}$ content in $\mathrm{CFA}$ is $7 \pm 3 \mathrm{wt} \%,{ }^{35}$ resulting in relatively low values of effective $\mathrm{CO}_{2}$

70 mineral capture. The limited $\mathrm{CE}$ and relatively low net $\mathrm{CO}_{2}$ capture capacity have been strong

71 handicaps for the widespread implementation of CCS strategies for CFA. In spite of some

72 efforts to improve CE values, ${ }^{5,37}$ progress in this direction has been limited, mostly because the

73 mechanisms of CFA carbonation are not fully understood. For instance it has been assumed that

74 only the easily leached crystalline phases containing calcium (e.g., $\mathrm{CaO}$ and $\left.\mathrm{Ca}(\mathrm{OH})_{2}\right)$ were able

75 to feed the solution for CFA carbonation. ${ }^{30,33}$ However, a significant fraction $(\geq 50 \%)$ of $\mathrm{CaO}$

76 (and $\mathrm{MgO}$, which can also contribute to $\mathrm{CO}_{2}$ mineralization) in CFA is present in the not-so-

77 easily leachable amorphous aluminosilicate phase, which typically accounts for $\geq 70 \mathrm{wt} \%$ of

78 CFA. ${ }^{11}$ It is thus necessary to better understand the carbonation mechanisms of CFA and to

79 explore means to effectively leach the $\mathrm{Ca}$ and $\mathrm{Mg}$ present in such amorphous phase in order to

80 achieve the highest possible CE. Moreover, no work has evaluated the potential of CFA

81 carbonation as a means to achieving an effective CCUS by the simultaneous production of

82 valuable zeolite by-products, while trapping PTE. 
84 carbonation under mild hydrothermal conditions using alkaline (bi)carbonate solutions,

85 combined with the formation of zeolites and the effective capture of PTE present in CFA.

86 MATERIALS AND METHODS

study was provided by the Compostilla thermal power plant in León (Spain). The concentrations

89 of major/minor and trace elements in unreacted CFA were determined on a Bruker AXS S4

90 Pioneer X-ray fluorescence (XRF) equipment. Identification and quantification of mineral

91 phases in unreacted CFA and solid products collected after carbonation experiments (see below)

92 was performed by powder X-ray diffraction (XRD), using a X'Pert PRO diffractometer

93 (PANalytical) with the following instrumental parameters: $\mathrm{Cu}-\mathrm{K} \alpha$ radiation, Ni filter, $40 \mathrm{~mA}$

94 current, $45 \mathrm{kV}$ tension, $3-70^{\circ} 2 \theta$ exploration range, $0.004{ }^{\circ} 2 \theta$ step size, and $29.84 \mathrm{~s}$ per step.

95 The HighScore Plus 2.2.4 software (PANalytical) was used to process the XRD patterns and to

96 identify mineral phases by matching the experimental diffraction patterns to those included in

97 the PDF-2 database. ${ }^{38}$ Quantitative mineralogical analysis was performed by Rietveld analysis ${ }^{39}$

98 using the Internal Reference Method $^{40}$ (5 wt $\%$ crystalline Si powder added as internal standard)

99 and the crystal structures provided by the American Mineralogist Crystal Structure Database

100 (Supplementary Material Table S1). Solids were also analysed by Fourier transform infrared

101 spectroscopy (FTIR) with an attenuated total reflectance (ATR) sample holder (Jasco 6200

102 FTIR) in the frequency range $400-4000 \mathrm{~cm}^{-1}$, with a spectral resolution of $2 \mathrm{~cm}^{-1}$, step size of 
104 Toledo) were performed under flowing $\mathrm{N}_{2}$ using a linear heating rate of $20^{\circ} \mathrm{C} \mathrm{min}^{-1}$, from 30 to

$105950{ }^{\circ} \mathrm{C}$. Reactant CFA and solid products were also analyzed by field emission scanning 106 electron microscopy (FESEM, Auriga Carl Zeiss SMT) equipped with energy dispersive X-ray

107 spectroscopy (EDS). Prior to analysis, solids were carbon coated. Further ultrastructural and

108 compositional details of reactant and product phases were studied by means of transmission

109 electron microscopy (TEM) on a FEI TITAN at $300 \mathrm{kV}$ acceleration voltage, and equipped with

110 a high angle annular dark field detector (HAADF) for Z-contrast imaging. Analytical electron

111 microscopy (AEM) was performed by EDS microanalysis (under scanning-TEM operation

112 mode) using the thin-foil method ${ }^{41}$ and $k$-factors determined using standard minerals of known

113 composition. Once each carbonation run was completed, the concentration of selected ions in

114 solution after filtration was determined by ICP-OES (Perkin Elmer, Optima 8300 or Varian

115 720ES). Finally, $\mathrm{N}_{2}$ sorption isotherms of unreacted CFA and carbonation products were

116 performed at $77 \mathrm{~K}$ on a TriStar 3000 equipment (Micromeritic), after sample degassing at 150

$117{ }^{\circ} \mathrm{C}$ for $12 \mathrm{~h}$ under vacuum (0.07 torr) in a Flow Prep device (Micromeritics).

118 CFA carbonation experiments. To disclose the effect of $\mathrm{pH}$ and background electrolyte

119 on carbon capture and zeolite synthesis efficiency, direct carbonation experiments in aqueous

120 solution were performed under hydrothermal conditions $\left(150{ }^{\circ} \mathrm{C}\right)::^{33}$ (i) without dissolved

121 inorganic carbon (DIC) (control, A-experiments), and (ii) with dissolved sodium or potassium

122 (bi)carbonate $(\mathrm{N}-$, and $\mathrm{K}$-experiments, respectively). Table 1 shows details of the different 
experimental runs. A $T$ of $150{ }^{\circ} \mathrm{C}$ was selected to favour the dissolution of mullite and quartz

124 present in the unreacted material. ${ }^{42} 0.0043 \mathrm{~mol} \mathrm{~mL}^{-1} \mathrm{Na}_{2} \mathrm{CO}_{3}, \mathrm{NaHCO}_{3}, \mathrm{~K}_{2} \mathrm{CO}_{3}$ and $\mathrm{KHCO}_{3}$

125 solutions were prepared using ultrapure MilliQ water (resistivity $18.2 \mathrm{M} \Omega \cdot \mathrm{cm}$, Millipore) and

$126>97 \%$-grade solid reactants from Sigma-Aldrich. A relatively high reactant concentration was

127 selected in order to ensure an excess of carbonate and to achieve a range of $\mathrm{pH}$ values from $\sim 8$

128 up to $\sim 12$. In a previous work we showed that a similar alkali (bi)carbonate reactant

129 concentration was optimal for the carbonation of pseudowollastonite $\left(\mathrm{CaSiO}_{3}\right){ }^{43}$ Note that such

130 alkali metal (bi)carbonate solutions are a proxy for alkali metal hydroxide solutions in which

$131 \mathrm{CO}_{2}$ gas is dissolved, and the solutions can be regenerated via $\mathrm{CO}_{2}$ injection, ${ }^{5}$ which could be

132 the actual protocol for implementing ex situ carbonation involving $\mathrm{CO}_{2}$ capture at emission

133 point sources. $1 \mathrm{~mL}$ of the solutions was added to $500 \mathrm{mg}$ of CFA in a PTFE vessel

134 (polytetrafluoroethylene, $3 \mathrm{~mL}$ total volume). Afterwards, the PTFE vessel was inserted into a

135 steel reactor designed for high $T$ - $P$ conditions. After sealing, the reactors were heated to $150{ }^{\circ} \mathrm{C}$

136 for $72 \mathrm{~h}$ (longer runs for up to 7 days showed no additional changes in the progress of the

137 reaction). Then, the autoclaves were cooled down to room $T$ and opened. The content of the

138 vessels was immediately filtered $(0.2 \mu \mathrm{m}$ membrane filter, Millipore $)$ and the solids were oven-

139 dried for $24 \mathrm{~h}$ at $60^{\circ} \mathrm{C}$. The $\mathrm{pH}$ of the solutions before and after the experiments was measured at

140 room $T$ using a glass electrode $($ Metrohm) calibrated with three standard solutions $(\mathrm{pH}=4.01$,

1417.01 and 10.01 at $25^{\circ} \mathrm{C}$ ) with \pm 0.01 uncertainty. In order to ensure statistical representativity, all

142 runs were performed in triplicate. 
144 crystalline $\mathrm{Ca}$ - and $\mathrm{Mg}$-containing phases (excluding already formed $\mathrm{CaCO}_{3}$ ) in unreacted CFA

145 can contribute to the leaching of $\mathrm{Ca}$ and $\mathrm{Mg}$ in solution and therefore, to the effective

146 carbonation of CFA. ${ }^{35,44}$ Multiple equations have been proposed to calculate the $\mathrm{CE}$ for $\mathrm{CO}_{2}$

147 sequestration. ${ }^{5,28,30,37,45,46}$ In this study, we calculated the $\mathrm{CaO}$ contained in the calcite present in

148 unreacted CFA using eq. 1:

$149 \mathrm{iCaO}=w t_{\mathrm{CaCO} 3} \times \frac{M_{\mathrm{CaO}}}{M_{\mathrm{CaCO} 3}}=0.56 w t \%$

150 where $w t_{\mathrm{CaCO} 3}$ is the $\mathrm{wt} \%$ of $\mathrm{CaCO}_{3}$ determined by the $\mathrm{XRD}$ analysis of the unreacted material

151 using the Rietveld method, $M_{\mathrm{CaCO} 3}$ is the molar mass of $\mathrm{CaCO}_{3}\left(100 \mathrm{~g} \mathrm{~mol}^{-1}\right)$ and $M_{\mathrm{CaO}}$ is the

152 molar mass of $\mathrm{CaO}\left(56 \mathrm{~g} \mathrm{~mol}^{-1}\right) \cdot i \mathrm{CaO}$ is subtracted from the total $\mathrm{CaO}+\mathrm{MgO}$ content of the

153 unreacted material, to determine the theoretical sequestration capacity of our CFA using the

154 Stenoir formula, ${ }^{28,45,46}$

$155 T h_{C c}=\left(w t_{C a O}-i C a O\right)+w t_{M g O}=4.87 w t \%$

156 where $w t_{\mathrm{CaO}}$ and $w t_{\mathrm{MgO}}$ are the content of $\mathrm{CaO}$ and $\mathrm{MgO}$, respectively, in unreacted material

157 measured by XRF. Finally, we adapted the equation used by Dananjayan et al. ${ }^{28}$ to calculate CE

$158(\%)$ as follows:

$159 C E=\frac{\left[\left(\Delta w t \% 590^{\circ} \mathrm{C}-800^{\circ} \mathrm{C}\right) \times\left(M_{(\mathrm{Ca}, \mathrm{Mg}) \mathrm{CO} 3} / M_{\mathrm{CO} 2}\right)\right]-1}{\operatorname{ThCC}} \times 100$

160 where $\left(\Delta w t \% 590^{\circ} \mathrm{C}-800^{\circ} \mathrm{C}\right)$ was calculated from TGA analyses, and $M_{(\mathrm{Ca}, \mathrm{Mg}) \mathrm{CO} 3}$ is the molar

161 mass of calcite in the products, which can include a fraction of $\mathrm{Mg}$ replacing $\mathrm{Ca}$ (i.e., $\mathrm{Mg}$ -

162 calcite) (see Results below). 
164 evaluate the PTE leaching capacity of both the unreacted and reacted CFA. Leaching 165 experiments were performed at $25{ }^{\circ} \mathrm{C}$ using PTFE reactors $\left(\mathrm{V}_{\text {tot }}=30 \mathrm{~mL}\right.$; lined with double 166 polycarbonate $0.2 \mu \mathrm{m}$ filters to prevent solids loss) under constant magnetic stirring. $1 \mathrm{~g}$ of 167 solids was placed in each reactor and the experiments started by continuously flowing MilliQ 168 water at a rate of $2 \mathrm{~mL} \mathrm{~min}^{-1}$. In order to evaluate the effect of $\mathrm{pH}$ on PTE leaching, experiments 169 were performed at a near-neutral $\mathrm{pH} 6$ and at an alkaline $\mathrm{pH} 10$ (adjusted using $1 \mathrm{M} \mathrm{NaOH}$ ), the 170 latter corresponding to the natural $\mathrm{pH}$ of the studied CFA (Table 1). Aliquots of the effluent 171 solution were collected at predefined time intervals $(30 \mathrm{~min}, 60 \mathrm{~min}, 90 \mathrm{~min}, 3 \mathrm{~h}, 6 \mathrm{~h}, 9 \mathrm{~h}$ and 24

172 h) and their PTE content was determined by ICP-MS on a NexION 300D equipment.

\begin{tabular}{llcccccc}
\hline Code & Solutions & Initial $\mathrm{pH}$ & Final $\mathrm{pH}$ & $\begin{array}{c}\text { Zeolitic content } \\
(\mathrm{wt} \%)\end{array}$ & $\begin{array}{c}\text { Carbonate content } \\
(\mathrm{wt} \%)\end{array}$ & $\begin{array}{c}\text { Mg content } \\
(\mathrm{mol} \%)\end{array}$ & $\begin{array}{c}\mathrm{CE} \\
(\%)\end{array}$ \\
\hline $\mathrm{A} 1$ & MilliQ $\mathrm{H}_{2} \mathrm{O}$ & 9.26 & 9.8 & 0 & 1 & 0 & 0 \\
$\mathrm{~N} 1$ & $3.4 \mathrm{M} \mathrm{Na}_{2} \mathrm{CO}_{3}$ & 11.63 & 10.77 & 60 & 4.9 & 1.19 & 79.26 \\
$\mathrm{~N} 2$ & $3.4 \mathrm{M} \mathrm{NaHCO}_{3}$ & 8.26 & 9.79 & 0 & 3.2 & 7.74 & 34.29 \\
$\mathrm{~K} 1$ & $3.4 \mathrm{M} \mathrm{K}_{2} \mathrm{CO}_{3}$ & 12.02 & 11.35 & 33 & 3 & 1.36 & 44.96 \\
$\mathrm{~K} 2$ & $3.4 \mathrm{M} \mathrm{KHCO}_{3}$ & 8.2 & 9.32 & 0 & 2.6 & 2.43 & 33.88 \\
\hline
\end{tabular}

173 Table 1. Experiment codes, solution composition, initial and final $\mathrm{pH}$, zeolitic content, 174 carbonate content, $\mathrm{Mg}$ content in calcite and Carbonation Efficiency (CE) for each experimental 175 run.

\section{RESULTS AND DISCUSSION}

178 Chemistry and mineralogy of unreacted CFA. XRF analysis (Table S2) shows that Si, Al and

179 Fe account for more that $80 \mathrm{wt} \%$ (expressed as oxides) of the CFA. Compositionally, this CFA 

can be classified as Class F, the most common and abundant type of CFA worldwide ${ }^{47}$. The

181 relatively low $\mathrm{CaO}$ plus $\mathrm{MgO}$ content (5.43 wt\%), which approaches the average alkaline-earth

182 metal oxide content of $\mathrm{CFA}^{35}$, poses a limit to the maximum net $\mathrm{CO}_{2}$ capture capacity of this

183 CFA. Several PTE are present in significantly high concentrations (e.g., $B a=1345$ ppm; V=849;

$184 \mathrm{Cr}=189 ; \mathrm{As}=150 \mathrm{ppm})$, also on the same range of concentrations reported for other $\mathrm{CFAs}^{11,48}$.

185 These results underline the potential toxicity of CFA leachates. XRD analysis (Figure 1a) shows

186 that this CFA is composed of a glass fraction $(95 \pm 2 \mathrm{wt} \%)$, graphite $(2.0 \pm 0.1 \mathrm{wt} \%)$, quartz

$187(1.2 \pm 0.1 \mathrm{wt} \%)$, mullite $(1 \pm 0.1 \mathrm{wt} \%)$, calcite $(1 \pm 0.1 \mathrm{wt} \%)$ and traces of hematite $(<1 \mathrm{wt} \%)$. The

188 presence of calcite in the unreacted fly ash is likely due to partial hydration of free $\mathrm{CaO}$ to

$189 \mathrm{Ca}(\mathrm{OH})_{2}$ and its subsequent carbonation to $\mathrm{CaCO}_{3}$ during sample handling. Due to the low

190 calcite content in this CFA, very low intensity (not easily visible) carbonate bands were detected

191 in FTIR spectra (Figure 1b). FTIR analysis also shows high intensity bands at $1009 \mathrm{~cm}^{-1}$ and

$192650-720 \mathrm{~cm}^{-1}$, corresponding to the asymmetric and symmetric vibration of $\mathrm{T}-\mathrm{O}(\mathrm{T}=\mathrm{Si}$ or $\mathrm{Al})$,

193 respectively, and at $400-500 \mathrm{~cm}^{-1}$, corresponding to $\mathrm{T}-\mathrm{O}$ bending as well as combination modes

194 of the aluminosilicate glass. ${ }^{49,50}$ FESEM observations show that the CFA is made up of spheres

195 and cenospheres (and a few plerospheres) with size $\leq 20 \mu \mathrm{m}$ (Supplementary Material, Fig. S1).

196 TEM-AEM analysis shows that this CFA is mainly composed of amorphous (see diffuse haloes

197 in SAED patterns) micrometer-sized aluminosilicate glass spheres and scarce C-rich aggregates

198 with embedded aluminosilicate spheres (Fig. S2). AEM point analyses (Table S3) yield the

199 following overall composition (wt\%) for the spheres $(\mathrm{N}=6): 50.7 \pm 2.5 \mathrm{SiO}_{2}, 32.7 \pm 1.8 \mathrm{Al}_{2} \mathrm{O}_{3}$, 

selected PTE: $\mathrm{V}=633$ ppm, As= 416 ppm, Mn= 66 ppm; $\mathrm{Cr}=16 \mathrm{ppm} ; \mathrm{Zn}=66 \mathrm{ppm}$, values consistent with XRF results. agreement with that reported by Moreno et al. ${ }^{11}$ for CFA from the same source and, despite the reported variability, ${ }^{35}$ is very similar to that of other Class F CFAs. ${ }^{9,18-23,30,31}$ We are thus confident that our CFA is representative for Class F CFAs from several coal-fired power plants. in the range 20-65\%). ${ }^{51}$ Analcime $(8 \pm 2 \mathrm{wt} \%)$, Na-chabazite $(17 \pm 6 \mathrm{wt} \%)$, NaP1 zeolite $(31 \pm 9$ $\mathrm{wt} \%$ ), and hydroxysodalite $(4 \pm 1 \mathrm{wt} \%)$ are identified, along with calcite ( $5 \pm 1 \mathrm{wt} \%)$, hematite 
221 hematite $(<1 \mathrm{wt} \%)$, quartz $(<1 \mathrm{wt} \%)$, mullite $(<1 \mathrm{wt} \%)$ and glass $(61 \pm 14 \mathrm{wt} \%)$. XRD analyses

222 show no zeolites, nor any changes in terms of phase composition in N2, K2 and control (A1)

223 runs, as compared with unreacted CFA.
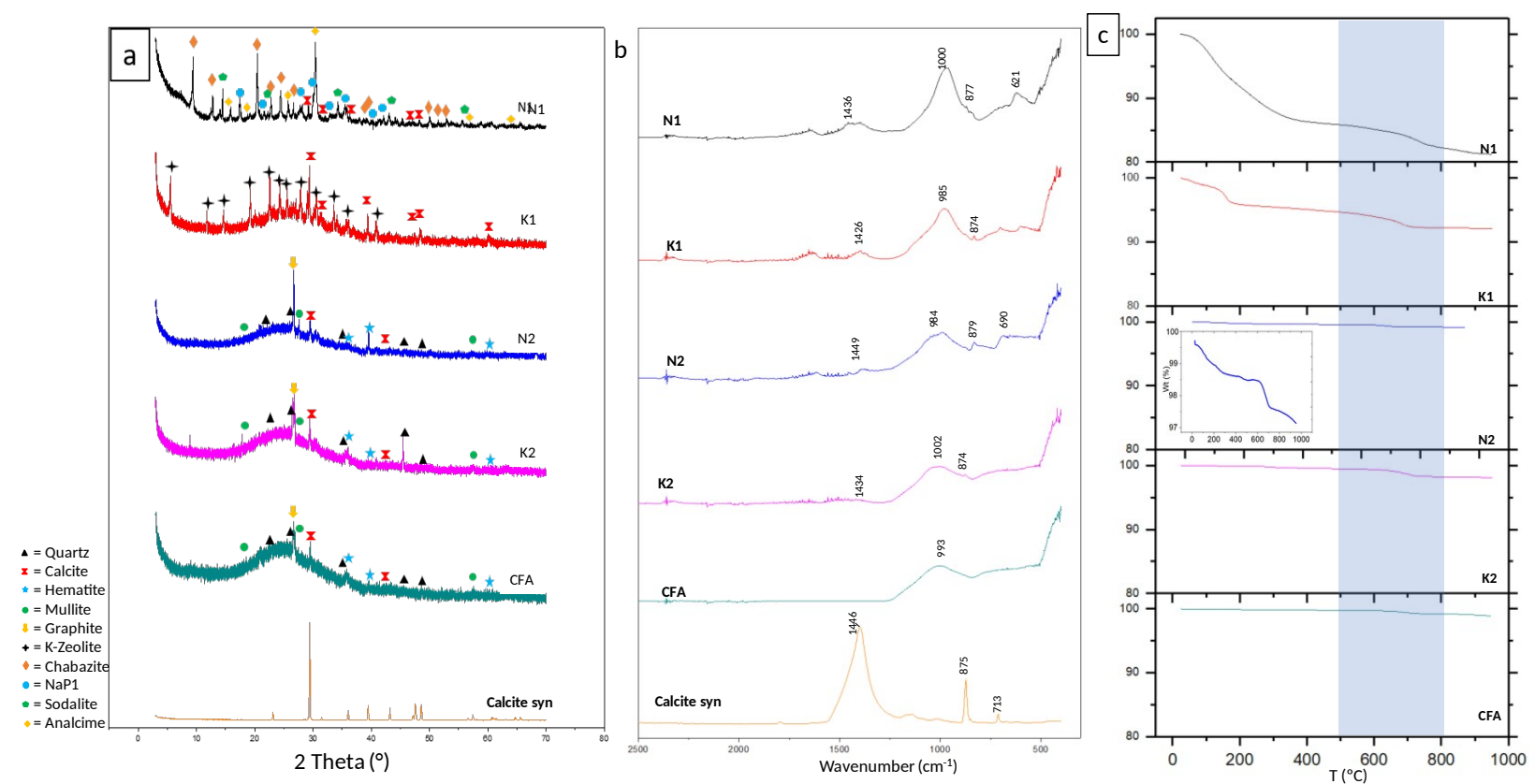

225 Figure 1. Unreacted CFA and products of its reaction in different carbonate solutions at $150^{\circ} \mathrm{C}$;

$226 \mathrm{Na}_{2} \mathrm{CO}_{3}(\mathrm{~N} 1), \mathrm{K}_{2} \mathrm{CO}_{3}(\mathrm{~K} 1), \mathrm{NaHCO}_{3}(\mathrm{~N} 2), \mathrm{KHCO}_{3}(\mathrm{~K} 2)$. (a) XRD patterns showing the Bragg

227 peaks of the different crystalline phases; legend in inset; (b) FTIR spectra; and (c) TGA traces

228 (insets show TGA traces with enlarged Y-axis). The shaded blue area represents the starting and 229 the final $T$ of carbonate decomposition $\left(550-800^{\circ} \mathrm{C}\right)$. FTIR spectra of samples K2, N2, K1 and N1 show well-defined bands at $\sim 710 \mathrm{~cm}^{-1}$,

$231 \sim 875 \mathrm{~cm}^{-1}$ and/or $\sim 1440 \mathrm{~cm}^{-1}$ that confirm the new-formation of calcite (Fig. 1b). They also

232 show the broad band at $\sim 1000 \mathrm{~cm}^{-1}$ (T-O asymmetric stretching) of aluminosilicate phases.

233 Bands at $\sim 650-870 \mathrm{~cm}^{-1}$ corresponding to the T-O symmetric stretching, at $\sim 442-503 \mathrm{~cm}^{-1}$

234 corresponding to the T-O bending, and at $550-575 \mathrm{~cm}^{-1}$ corresponding the double rings of 
235 analcime ${ }^{52}$ sodalite, $\mathrm{NaP} 1$ zeolite and Na-chabazite, ${ }^{52}$ as well as K-zeolite, ${ }^{53}$ are observed in

236 runs N1 and K1 respectively. Solids collected after runs N2 and K2 (bicarbonate runs) show

237 similar T-O band as those described above. They also show the broad band at $\sim 1000 \mathrm{~cm}-1$ (T-O

238 asymmetric stretching), and less intense (and poorly resolved) bands at $\sim 650-870 \mathrm{~cm}-1$ (T-O

239 symmetric stretching) and the very intense, broad band at $\sim 400-500 \mathrm{~cm}-1$ corresponding to the

240 T-O bending of aluminosilicate phases, consistent with the presence of unreacted CFA and

241 newly-formed zeolites (in the case of runs N1 and K1) (confirmed by TEM-SAED analysis, see

242 below). ${ }^{54-56}$ No changes are detected in the FTIR spectra of the control run (A1) as compared

243 with that of unreacted CFA. In combination with XRD, the FTIR results further demonstrate

244 that a hydrothermal treatment with pure water leads to no mineral or structural changes to CFA. TG-DSC analyses (Fig. 1c) show that the starting material and all products display a

246 weight loss in the temperature range $550-800^{\circ} \mathrm{C}$, related to the thermal decomposition of calcium

247 carbonate according to the reaction $\mathrm{CaCO}_{3}=\mathrm{CaO}+\mathrm{CO}_{2} \cdot{ }^{57}$ However, we observe that the

248 starting $T$ for the thermal decomposition of carbonates differ among runs, suggesting that either

249 there are changes in calcite particle size (smaller size-fractions decomposing at lower $T$ than

250 larger size-fractions) and/or that $\mathrm{Mg}$ partially replaces $\mathrm{Ca}$ in the calcite phase, forming a (low)

251 Mg-calcite, therefore lowering the starting decomposition temperature. ${ }^{58,59}$ Note that XRD

252 analyses show no (crystalline) magnesium carbonates. We performed unit-cell refinement using

253 Rielveld analysis to determine the $\mathrm{Mg}$ content in calcite using the method proposed by

254 Goldsmith and Graff $(1958)^{60}$ (results in Table 1). Calcite in unreacted CFA has no Mg. The 
255 highest Mg content in newly-formed calcite is observed in N2 runs, followed by $\mathrm{K} 2$, $\mathrm{K} 1$ and N1

256 runs. These results are in full agreement with TGA results and with the first derivate of the DSC

257 analyses (Figure S3), showing a lower starting decomposition $T$ for the Mg-calcites with the

258 highest $\mathrm{Mg}$ content. We suggest that at a moderately alkaline $\mathrm{pH}$ (bicarbonate runs), the higher

$259\left[\mathrm{Ca}^{2+}\right] /\left[\mathrm{CO}_{3}{ }^{2-}\right]$ ratio (closer to unity) as compared to higher $\mathrm{pH}$ runs (with higher $\left[\mathrm{CO}_{3}{ }^{2-}\right]$ ) could

260 enable faster calcite growth favoring $\mathrm{Mg}$ incorporation. ${ }^{61}$ From the weight loss in the $T$ range

$261550-850{ }^{\circ} \mathrm{C}, \mathrm{CE}$ values of $34 \%, 34 \%, 45 \%$ and $79 \%$ are obtained for $\mathrm{K} 2, \mathrm{~N} 2, \mathrm{~K} 1$ and $\mathrm{N} 1$ runs,

262 respectively. TGA analyses show an additional weight loss at $105-200^{\circ} \mathrm{C}$ in $\mathrm{N} 1, \mathrm{~K} 1, \mathrm{~N} 2$ and $\mathrm{K} 2$

263 runs. In the case of $\mathrm{N} 1$ and $\mathrm{K} 1$ runs, this is likely due to loss of zeolitic water. Conversely, in

264 runs $\mathrm{N} 2$ and $\mathrm{K} 2$, which lack crystalline zeolites, the weight loss is likely due to the

265 decomposition of residual $\mathrm{NaHCO}_{3}$ and $\mathrm{KHCO}_{3}$ according to the reaction $2 \mathrm{MHCO}_{3}=\mathrm{M}_{2} \mathrm{CO}_{3}+$

$266 \mathrm{CO}_{2}+\mathrm{H}_{2} \mathrm{O}$, where $\mathrm{M}$ is a monovalent cation $(\mathrm{K}$ or $\mathrm{Na})$. However, we cannot rule out the

267 possibility that this weight loss is due to dehydration of an amorphous zeolitic precursor. In any

268 case, it should be noted that $\mathrm{Na}_{2} \mathrm{CO}_{3}$ and $\mathrm{K}_{2} \mathrm{CO}_{3}$ (if present as a residual) would undergo melting

269 at $850^{\circ} \mathrm{C}$ and $900^{\circ} \mathrm{C}$, respectively, therefore not interfering with the calcium carbonate

270 decomposition, nor releasing any $\mathrm{CO}_{2}$ at lower $T .^{62}$ In all runs, including the control and

271 unreacted CFA, the limited initial weight loss at $T<550{ }^{\circ} \mathrm{C}$ is likely due to dehydration of

272 amorphous silica. ${ }^{43}$ Note that such a weight loss overlaps with the weight loss associated with

273 zeolitic water in runs where zeolites (and zeolitic precursors) are formed.

274 FESEM images show the presence of calcite (as indicated by XRD analysis) in all 
275 carbonation runs (Fig. 2). Calcite appears as micrometer sized rhombohedral crystals attached to

276 CFA spheres (Fig. 2b-c). Reacted CFA spheres have irregular surfaces coated by newly formed

277 precipitates (Fig. 2b-c). It was, however, not possible to clearly differentiate by EDS

278 microanalysis the composition of these precipitates from that of the unreacted spheres.

279 According to Murayama et al. ${ }^{20}$ these coatings are most likely composed by new Si-Al phases

280 formed after partial dissolution of the spheres and re-precipitation at the sphere-solution

281 interface. Such newly-formed precipitates could act as a passivation layer on CFA particles,

282 acting in a similar way as the amorphous silica-rich surface layers formed during weathering of

283 primary silicate minerals. ${ }^{63-66}$ SEM-EDS analysis corroborates XRD analyses showing the

284 presence of NaP1 (Fig. 2d), Na-chabazite (hershelite) (Fig. 2e), hydroxysodalite/cancrinite, and

285 analcime (Fig. 2f) in N1 run, and K zeolite in K1 run (Fig. 2g). ${ }^{9,52}$ SEM-EDS analysis also show

286 that $\mathrm{Sr}, \mathrm{W}$ and $\mathrm{Ce}$ are incorporated into the newly formed carbonates (Fig. S4a-b), V is trapped

287 in zeolite phases, and $\mathrm{Cu}$ is incorporated in both newly-formed phases (Fig. S4c-d). Conversely,

288 SEM-EDS analysis of carbonates formed in N2 and K2 experiments shows no trapping of PTE,

289 although we observe the presence of scattered shapeless coatings on some CFA spheres (Fig.

290 2h), likely corresponding to an amorphous zeolitic precursor, ${ }^{55}$ as confirmed by TEM-SAED and

291 AEM analyses (see below). Due to the background signal from the underlying spheres we could

292 not clearly determine using EDS microanalysis whether or not PTE are trapped in these latter

293 precipitates. We argue that the extensive dissolution of the glass particles in $\mathrm{N} 1$ and $\mathrm{K} 1 \mathrm{runs}$

294 favored the release and subsequent trapping of PTE into the newly formed carbonate and zeolite 
295 phases. No trapping of PTE into the limited amount of newly formed crystalline phases (i.e.,

296 carbonates) in runs N2 and K2 is detected by SEM-EDS, likely due to the limited dissolution

297 and PTE release from the glass phase Yet it is likely that the newly-formed amorphous zeolitic

298 precursors formed in the bicarbonate runs also trapped PTE (see TEM-AEM results below).

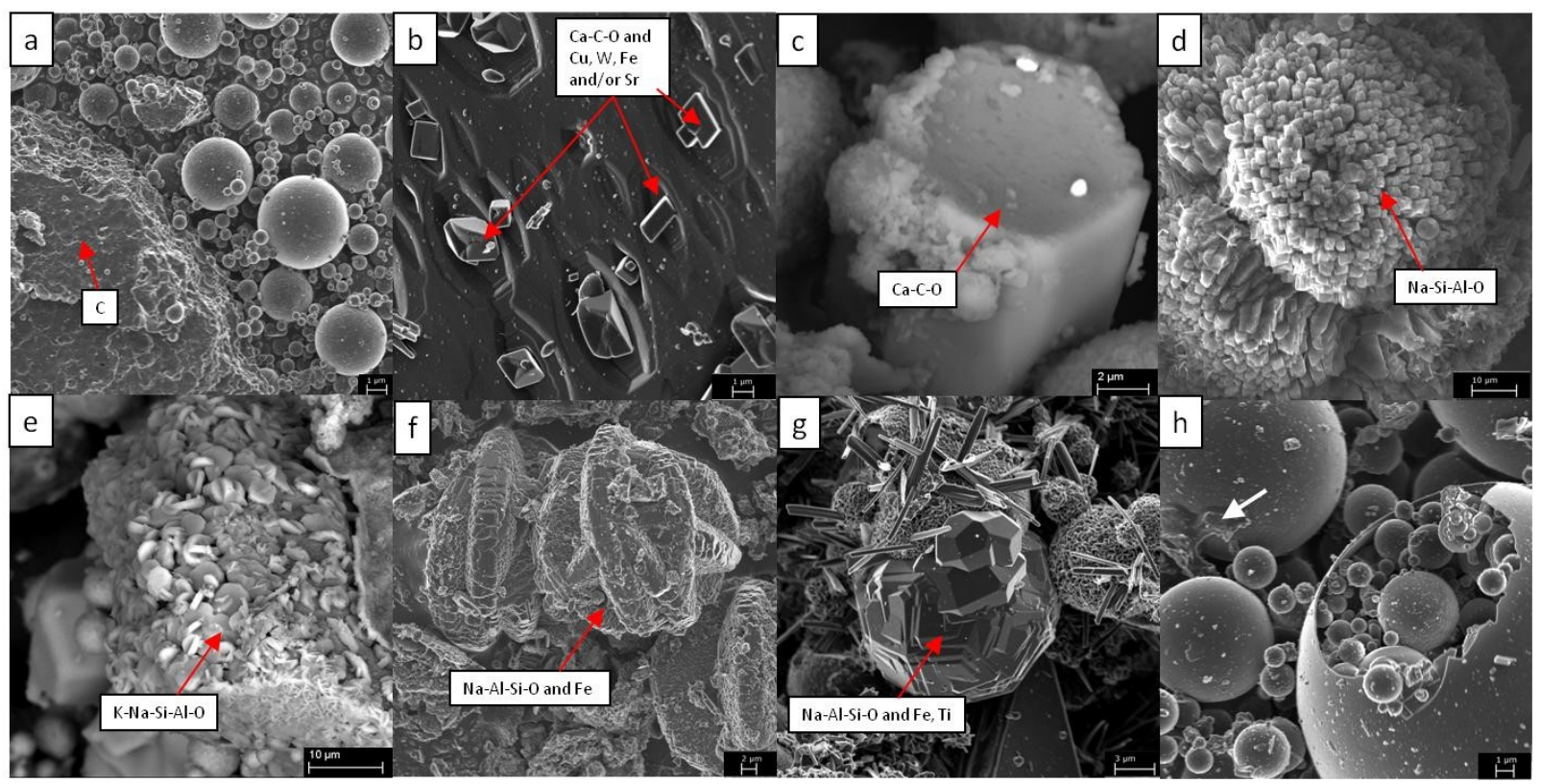

300 Figure 2. FESEM images of: (a) unreacted spheres of CFA and a graphite (C) particle; (b)

301 calcite in N1; (c) calcite in K1; (d) NaP1 zeolite in N1; (e) K-zeolite in K1; (f) Na-chabazite

302 (hershelite) in $\mathrm{N} 1$; (g) analcime in $\mathrm{N} 1$; and (h) large plerosphere (lower left) and solid spheres in 303 run N2. The white arrow points to a shapeless deposit with features resembling an amorphous 304 zeolitic precursor. The EDS elemental composition of the red-arrowed particles are shown in the 305 insets.

TEM-AEM analysis of reacted CFA shows significant mineralogical and compositional

(Fig. 3). Aggregates of newly formed poorly crystalline zeolitic nanophase with diffuse Debye 
311 SAED pattern (Fig. 3b). HAADF images and corresponding EDS maps confirm the formation

312 Na-zeolites, which include different PTE (Fig. 3c-d).
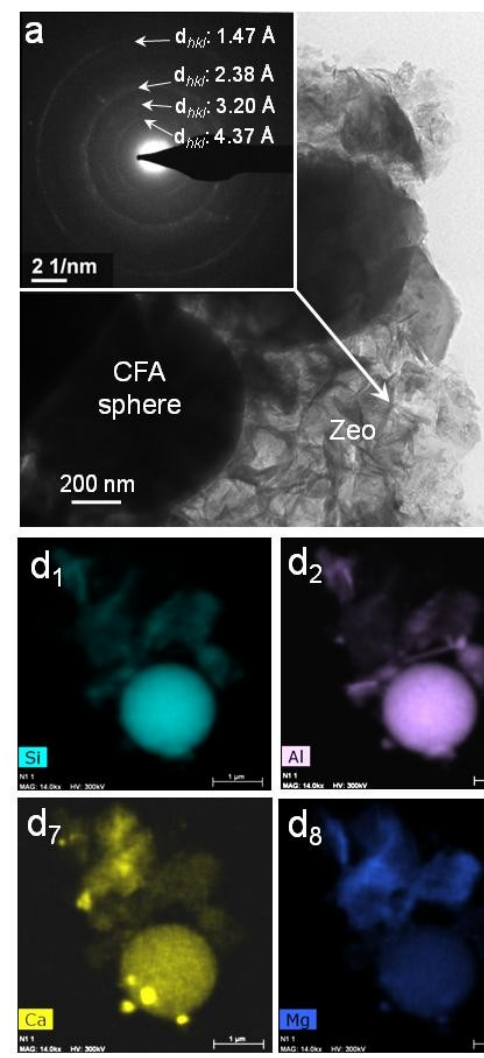
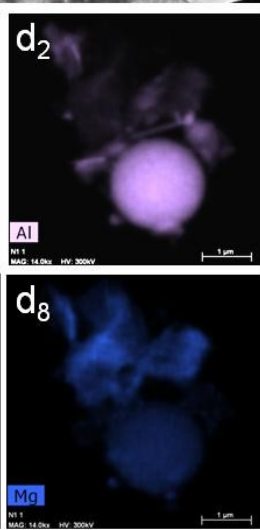
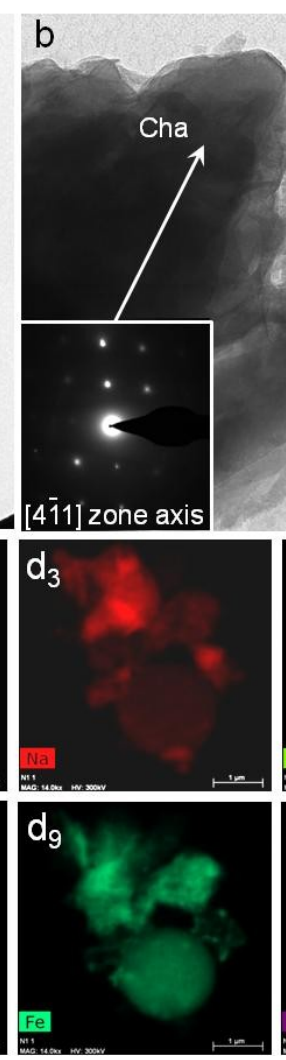
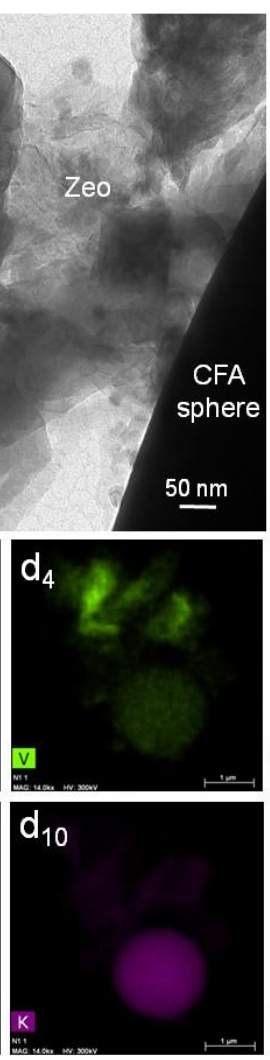
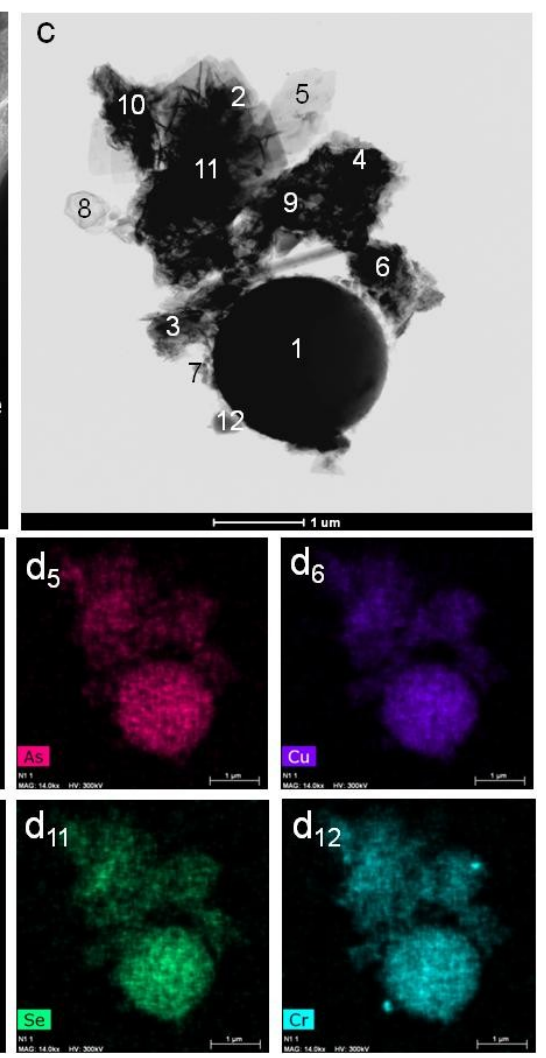

314 Figure 3. TEM-AEM analysis of reaction products of run N2. (a) Relict CFA sphere and newly

315 formed zeolites (Zeo). The inset shows the SAED of the aggregate at the lower right. The

316 diffuse Debye ring at the indicated d-spacing show the presence of a poorly crystlline precursor

317 phase to Na-chabacite; (b) Large well-crystallized Na-chabazite (its [4-11] zone axis SAED

318 pattern is shown in inset); (c) HAADF image of a sphere surrounded by newly-formed product

319 phase. The numbers indicate AEM point analyses with composition reported in Table S4. (d1-

320 d12) EDS elemental maps of the particles shown in (c). 
325 hydroxysodalite with formula $\mathrm{Na}_{5.53} \mathrm{~K}_{0.14} \mathrm{Mg}_{0.09} \mathrm{Fe}_{0.24} \mathrm{Al}_{4.71} \mathrm{Si}_{6} \mathrm{O}_{24}(\mathrm{OH})_{2} \cdot 2 \mathrm{H}_{2} \mathrm{O}$ (analysis 6 in Table

326 S4) plus a Na-poor aluminosilicate phase with a Si/Al ratio of 0.7 (analysis 12 in Table S4),

327 consistent with the presence of an amorphous (gel) zeolitic precursor. ${ }^{67,68}$ The zeolitic phases

328 include significant amounts of PTE: up to $500 \mathrm{ppm} \mathrm{Zn,} 300 \mathrm{ppm} \mathrm{V}$, and $800 \mathrm{ppm} \mathrm{Cu}$ in NaP1;

329 up to $1000 \mathrm{ppm} \mathrm{Cu}$, and $200 \mathrm{ppm}$ As in hydroxysodalite, and up to $600 \mathrm{ppm} \mathrm{Cu}, 500 \mathrm{ppm} \mathrm{Mn}$,

$330500 \mathrm{ppm} \mathrm{Zn,} 3600 \mathrm{ppm} \mathrm{Cr}$ and $2400 \mathrm{ppm} \mathrm{V}$ in the amorphous zeolitic precursor (Table S4).

331 Very similar results are observed in zeolitic products of run K1 (Fig. S5, Table S6), where K

332 zeolite with a representative formula $\mathrm{K}_{2.34} \mathrm{Na}_{0.62} \mathrm{Mg}_{0.68} \mathrm{Ca}_{0.11} \mathrm{Fe}_{0.22} \mathrm{Al}_{3.33} \mathrm{Si}_{9} \mathrm{O}_{24} \cdot 7 \mathrm{H}_{2} \mathrm{O}$ (analysis \#5,

333 Table S5) is identified. The newly formed K zeolite includes significant amounts of PTE: e.g.,

334 up to $424 \mathrm{ppm} \mathrm{V}$, up to $631 \mathrm{Cr}$ and up to $406 \mathrm{Mn}$. In the case of the bicarbonate runs, TEM-

335 SAED reveals the presence of aggregates made up of amorphous nanoparticles $\sim 20-50 \mathrm{~nm}$ in

336 size attached to the CFA spheres (Fig. S6). AEM analysis shows that in N2 runs they have a

337 formula $\mathrm{Na}_{3.56} \mathrm{~K}_{0.47} \mathrm{Ca}_{0.74} \mathrm{Al}_{5.97} \mathrm{Si}_{10} \mathrm{O}_{32} \cdot 12 \mathrm{H}_{2} \mathrm{O}$ (analysis \#3, Table S6), consistent with the

338 formation of a (NaP1) zeolitic precursor. Similar nanosized amorphous zeolitic precursors have

339 been observed previously. ${ }^{68,69}$ Interestingly, EDS mapping and AEM point analyses of CFA

340 spheres in this same run show Na-enrichment (up to $2 \mathrm{wt} \% \mathrm{Na}_{2} \mathrm{O}$; analysis \#2 in Table S6),

341 which points to formation of zeolitic precursors blanketing the sphere. A relative high

342 concentration of PTE such as $\mathrm{Cu}, \mathrm{V}$, and $\mathrm{Mn}$ is present in the reacted CFA spheres (Table S6).

343 Altogether, these TEM-AEM results demonstrate that PTE originally present in CFA are

344 preferentially incorporated into the newly-formed amorphous zeolitic precursor and zeolite 
345 phases.

346 Finally, Brunauer-Emmett-Teller (BET) analysis ${ }^{70}$ shows that the unreacted CFA and

347 the control A1 have a surface area of $1.1 \pm 0.1 \mathrm{~m}^{2} \mathrm{~g}^{-1}$, whereas $\mathrm{N} 1, \mathrm{~K} 1, \mathrm{~N} 2$ and $\mathrm{K} 2$ have a surface

348 area of $20.4 \pm 0.7 \mathrm{~m}^{2} \mathrm{~g}^{-1}, 4.3 \pm 0.1 \mathrm{~m}^{2} \mathrm{~g}^{-1}, 2.1 \pm 0.1 \mathrm{~m}^{2} \mathrm{~g}^{-1}$, and $1.2 \pm 0.1 \mathrm{~m}^{2} \mathrm{~g}^{-1}$, respectively. These

349 results show that the formation of zeolites in N1 and K1 runs significantly increases the surface

350 area, as expected for the presence of such microporous solids. They also show that the best

351 absorbent product is achieved using $\mathrm{Na}_{2} \mathrm{CO}_{3}$ as alkaline activator. Interestingly, in the case of

352 run N2, the surface area increases $\sim 100 \%$ as compared with unreacted CFA. This is consistent

353 with the formation of the amorphous zeolitic precursor detected with TEM, which reportedly are

354 nanosized and have a relatively high surface area. ${ }^{56}$ Following zeolite formation in run K1 and,

355 specially, in run N1, the isotherm of CFA changes from type II (typical of non-porous solids) to

356 a combination of type II and type IV with H4 hysteresis loop typical of micro/mesoporous solids

357 (Fig. S7). ${ }^{70}$ The hysteresis loop is not that well defined in run N2, is nearly absent in run K1, and

358 is completely absent in the unreacted CFA and control run A1. The latter further confirms that a

359 zeolitic precursor is formed in the former runs, particularly in run N2.

Factors affecting the progress of carbonation. The higher carbonation reached in

361 carbonate solutions $(\mathrm{K} 1, \mathrm{~N} 1)$ as compared to bicarbonate solutions $(\mathrm{K} 2, \mathrm{~N} 2)$ can be explained

362 considering the much higher initial $\mathrm{pH}$ of the former solutions. ${ }^{71} \mathrm{CFA}$ dissolution is significantly

$363 \mathrm{pH}-d e p e n d e n t$, increasing the dissolution rate with increasing $\mathrm{pH}^{9,18-22,72-74}$. This is similar to the

364 solubility trend of amorphous silica, which increases sharply for $\mathrm{pH}>9.0 .{ }^{62}$ Since $\mathrm{Ca}$ (and $\mathrm{Mg}$ ) 
must be free in solution to be available for carbonation, an increase in $\mathrm{pH}$ should result in an

366 increase in the amount of $(\mathrm{Mg})$ calcite formed ${ }^{75}$ Moreover, at $\mathrm{pH}>10.3$, the dominant $\mathrm{C}$ species

367 in solution is $\mathrm{CO}_{3}{ }^{2-}$ which is the species involved in the formation of carbonates, whereas at

$368 \mathrm{pH}<10.3, \mathrm{HCO}_{3}{ }^{-}$is the main aqueous $\mathrm{C}$ species, this limiting the extent of carbonation.

370 because the initial (and final) $\mathrm{pH}$ of the former run was higher that the latter one (Table 1). The

371 Ca concentration in solution (and also $\mathrm{Si}$ and $\mathrm{Al}$, see Fig. S8) was significantly higher in $\mathrm{K}_{2} \mathrm{CO}_{3}$

372 than in $\mathrm{Na}_{2} \mathrm{CO}_{3}$ experiments, although not much difference was observed in bicarbonate

373 experiments. This fact shows that the presence of $\mathrm{Na}^{+}$ions enhances the formation of crystalline

374 phases acting as "structure builders", whereas $\mathrm{K}^{+}$ions hamper the precipitation of secondary

375 phases, in agreement with Monasterio-Guillot et $\mathrm{al}^{62}$. Because $\mathrm{Na}^{+}$favours the precipitation of

376 secondary crystalline phases (carbonates and zeolites), a more thorough dissolution of the

377 amorphous $\mathrm{Ca}$ - and $\mathrm{Mg}$-containing aluminosilicate spheres occurs, shifting the reaction towards

378 the product side and fully explaining the contrasting results of N1 and K1 runs.

Factors affecting zeolite formation. Our results show that: (i) a wider variety of

experimental conditions, and (ii) higher zeolite yields are obtained with $\mathrm{Na}^{+}$as background ion,

382 in agreement with Zeng et al. ${ }^{42}$ Crystalline zeolites were not detected in bicarbonate solutions, or

383 in the controls with just water. Murayama et al. ${ }^{20}$ showed that the presence of high $\mathrm{OH}^{-}$ 
385 allows the formation of an aluminosilicate gel, which is the precursor of zeolites. In our work,

386 zeolites form due to a combination of the hydrothermal conditions $\left(T>120^{\circ} \mathrm{C}\right)$ and the alkaline

$387 \mathrm{pH}(>10)^{9,18-22,25,72-74}$. The release of $\mathrm{Al}$ and Si during dissolution of the CFA occurs in different

388 stages, initially beginning with the dissolution of the glass, which is the most reactive phase,

389 followed by quartz and mullite. ${ }^{19}$ Commonly, high concentrations of $\mathrm{NaOH}$ or $\mathrm{KOH}$ (typically 1

390 to $5 \mathrm{M})$ under hydrothermal conditions $\left(>120^{\circ} \mathrm{C}\right)$ have been used to promote the dissolution of

391 the glass fraction and the subsequent precipitation of zeolite-type phases. ${ }^{8,18,20-22,42,72,76}$

392 Interestingly, the high zeolite yield observed in the presence of $\mathrm{Na}^{+}$ions in run $\mathrm{N} 1$, which also

393 yields the maximum amount of calcium carbonate, suggests that a synergistic action is at work

394 during the precipitation of these phases. Apparently, higher levels of dissolution of the

395 amorphous aluminosilicates in CFA are favored by the joint formation of both carbonates and

396 zeolites, enabling a higher conversion of CFA into crystalline product phases. Remarkably, the

397 high zeolite yield observed here is achieved at relatively mild $T$ conditions with sodium

398 carbonate solutions with lower $[\mathrm{OH}]^{-}$concentrations than typically used for zeolite synthesis via

$399 \mathrm{NaOH}$ alkaline activation. Moreover, our route does not require alkali-fusion of CFA at high $T$

$400\left(>500^{\circ} \mathrm{C}\right)$, or the use of energy intensive microwave synthesis ${ }^{25}$, which is advantageous from an

401 economic and environmental point of view.

402

Toxic elements leaching. Unreacted CFA shows a general higher release of PTE to the

solution at both near-neutral and alkaline pHs as compared to reacted samples (Fig. 4). This

404 effect is most marked in runs $\mathrm{N} 1$ and $\mathrm{K} 1$, although solids from run N2 and $\mathrm{K} 2$ also show a 
405 significant reduction in PTE release. The release of As is pH-dependent for unreacted CFA, 406 being higher at $\mathrm{pH} 6$ than at $\mathrm{pH}$ 10. It has been reported that alkaline CFAs, like the one used 407 here, show higher As release rates at high $\mathrm{pH}$ than at low $\mathrm{pH}$, whereas the opposite is true for 408 acidic CFA. ${ }^{77}$ Release of As from unreacted CFA is eight times higher than in reacted CFA.

409 Such a huge difference is ascribed to its adsorption/entrapment into newly formed zeolites (or 410 zeolite precursors in bicarbonate runs). The behaviour of $\mathrm{V}$ and $\mathrm{Sb}$ (Figure S4c and f) is very 411 similar to that of $\mathrm{As}^{78}$, yet some subtle differences are observed. For instance, unreacted CFA 412 present a higher $\mathrm{Sb}$ release at near neutral $\mathrm{pH}$ than at alkaline $\mathrm{pH}$, whereas reacted samples show 413 the opposite behaviour. This is likely due to the incorporation of this element in non-silicate 414 phases (iron oxides) which prevent its release at acid-neutral $\mathrm{pH}$, but is solubilized at alkaline $415 \mathrm{pH}^{77}$ Regarding heavy metal ions such as $\mathrm{Cu}$, Mo and $\mathrm{Zn}$ (as well as $\mathrm{Sr}, \mathrm{Mn}$ and Ni) we observe 416 that their release rate is strongly $\mathrm{pH}$-dependent (Fig. 4). At alkaline $\mathrm{pH}$ a systematic reduction in 417 release rate occurs in reacted CFA as compared to unreacted CFA. This is consistent with the 418 trapping of these metals both in carbonate and zeolitic phases as shown by our TEM-AEM and 419 SEM-EDS. In the case of $\mathrm{Cu}$, this is likely due to its incorporation into zeolites as nanophase $420 \mathrm{Cu}(\mathrm{OH})_{2}$ or $\mathrm{CuO}$, as demonstrated by Terzano et al. ${ }^{79}$ In contrast, at $\mathrm{pH} 6$ all these elements 421 tend to be released at a higher rate in reacted than in unreacted CFA samples. A likely 422 explanation for this behaviour is the release of such metals from their calcite host after the 423 proton-promoted dissolution of the latter phase. Altogether, our results show that the 424 precipitation of secondary phases plays a key role in the immobilization of PTE. Our leaching 
425 results show that at alkaline conditions (i.e., the natural $\mathrm{pH}$ of this alkaline CFA), the PTE

426 release of reacted samples including zeolitic precursors, zeolites and calcite, is significantly

427 reduced as compared with raw CFA (i.e. As leaching in unreacted material ( $80 \mathrm{ppb}$ ) while in K2

428 run (1.9 ppb) in $\mathrm{pH} 6$; $\mathrm{V}$ leaching in unreacted material $80 \mathrm{ppb}$, while in $\mathrm{N} 2$ run $30 \mathrm{ppb}$ ).

429 However, at mildly acidic conditions, release of some specific PTE trapped in newly formed

430 carbonates might be an issue. Nonetheless, because after carbonation/zeolitization the $\mathrm{pH}$ of the

431 CFA remains alkaline, such an acid-promoted PTE release will be unlikely if, for instance, the

432 reacted CFA is disposed of in a pond or landfilled. Although CFA has been shown to be able to

433 adsorb different acid gasses, including $\mathrm{CO}_{2}$, and different PTE and organic pollutant, such an

434 adsorption is known to be very poor. ${ }^{80}$ Transformation of CFA into carbonates and zeolites can

435 overcome such limitations as it is shown here.
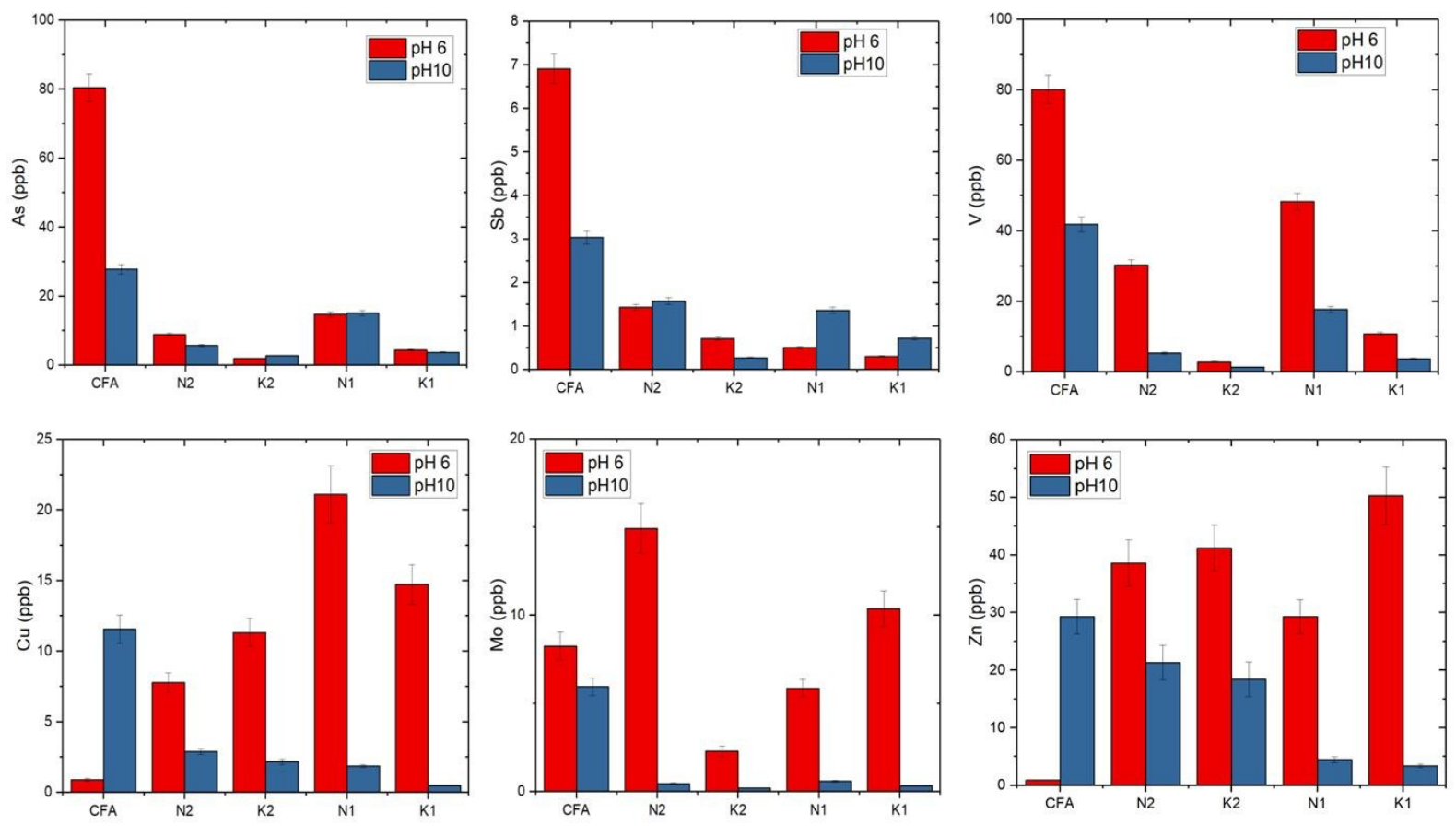

437 Figure 4. Results of leaching tests performed at $\mathrm{pH} 6$ and $\mathrm{pH} 10$. The total amount of selected 
438 elements (As, $\mathrm{Sb}, \mathrm{V}, \mathrm{Cu}, \mathrm{Mo}$, and $\mathrm{Zn}$ ) leached from the unreacted $\mathrm{CFA}$ as well as of product

439 from runs $\mathrm{N} 2, \mathrm{~K} 2, \mathrm{Ni}$ and $\mathrm{K} 1$ is presented. The total amount was calculated by integrating the

440 amount of element released at the predetermined sampling time intervals indicated in Materials 441 and Methods.

442

Implications. We demonstrate that 1 ton of CFA can contribute to the sequestration of

$44445 \mathrm{~kg}$ of $\mathrm{CO}_{2}$, a value that is much higher than those reported for other CFA, even with higher

$445 \mathrm{CaO}$ (and $\mathrm{MgO}$ ) contents. ${ }^{28,81-83}$ Still, this capacity is relatively small if compared with other

446 alkaline waste materials such as steel slag, cement kiln dust, municipal solid waste incinerator

447 (MSWI) ash or air pollution control (APC) residues where values of net $\mathrm{CO}_{2}$ mineral

448 sequestration up to $290 \mathrm{~kg}$ of $\mathrm{CO}_{2} / \mathrm{ton}$ of alkaline waste have been reported. ${ }^{35}$ However,

449 considering the amount of CFA produced annually worldwide, and the amount already

450 landfilled, CFA carbonation can effectively contribute to the reduction of the $\mathrm{C}$ footprint of the

451 coal-firing sector.

We also show that the background alkaline metal ion plays a key role in the carbonation

453 and zeolitization efficiency. The "structure builder" role of $\mathrm{Na}^{+}$, led to $60 \mathrm{wt} \%$ conversion of

454 CFA into zeolites, also reaching the highest CE of all runs $(79.26 \%)$. To our knowledge, these

455 values are among the highest ones obtained for zeolite conversion and carbonation efficiency

456 using CFA. ${ }^{18,19,52,73}$ In contrast, with $\mathrm{K}^{+}$as background electrolyte, only a $30 \%$ zeolitic yield and

457 about half the CE of the N1 run were achieved. These results demonstrate that the use of a

458 sodium alkaline solution for $\mathrm{CO}_{2}$ mineral capture and zeolite production is the best choice. 
460 hazardous these wastes for their disposal of in ponds or landfills, while simultaneously

461 increasing their value as a result of the formation of reaction byproducts (carbonates and

462 zeolites) with a potential commercial use in several applications, with promising capacities to

463 immobilize PTE from wastewaters, or for flue gas treatment and separation of different

464 greenhouse gases (e.g., $\mathrm{CO}_{2}, \mathrm{NH}_{4}$ ). Ultimately, our study opens a new pathway on the combined

465 carbonation and zeolitisation of CFA under hydrothermal conditions to add an extra value to

466 these wastes to form reusable materials and, also, to avoid the hazardous consequences due to

467 the leaching of potentially toxic elements.

468

469 Acknowledgement: This research has been funded by the Spanish Government (grant

470 RTI2018-099565-B-I00), European Commission (ERDF funds), the Junta de Andalucía

471 (research group RNM-179), and the University of Granada (Unidad Científica de Excelencia

472 UCE-PP2016-05). TGA-DSC analyses were partially funded by a grant from Labex

473 OSUG@2020 (investissements d'avenir, ANR10-LABX56). Use of the Analytical Chemistry

474 platform of ISTerre is acknowledged. LMG acknowledges funding by the Spanish Government

475 (Grant BES-2016-078468). We thank the personnel of the Centro de Instrumentación Científica

476 (CIC; University of Granada) for assistance with ICP-OES, ICP-MS, FESEM and TEM

477 analyses. We also thank M. Burgos for his help with $\mathrm{N}_{2}$ sorption analyses.

479 References

480 (1) IPCC. Climate Change 2014: Synthesis Report. Fifth Assesment Report of the 
482

483

484

485

486

487

488

489

490

491

492

493

494

495

496

497

498

499

500

501

0248(00)00575-3.

(2) Bhatt, A.; Priyadarshini, S.; Mohanakrishnan, A. A.; Abri, A.; Sattler, M.;

Techapaphawit, S. Physical, Chemical, and Geotechnical Properties of Coal Fly Ash: A

Global Review. Case Stud. Constr. Mater. 2019, 11, e00263.

(3) Wee, J. H. A Review on Carbon Dioxide Capture and Storage Technology Using Coal

Fly Ash. Appl. Energy 2013, 106, 143-151.

https://doi.org/10.1016/j.apenergy.2013.01.062.

(4) Blissett, R. S.; Rowson, N. A. A Review of the Multi-Component Utilisation of Coal Fly Ash. Fuel 2012, 97, 1-23.

(5) Ji, L.; Yu, H.; Wang, X.; Grigore, M.; French, D.; Gözükara, Y. M.; Yu, J.; Zeng, M.

CO2sequestration by Direct Mineralisation Using Fly Ash from Chinese Shenfu Coal.

Fuel Process. Technol. 2017, 156, 429-437. https://doi.org/10.1016/j.fuproc.2016.10.004.

(6) European Coal Combustion Products Association e.V.

(7) American Coal Ash Association's.

(8) Dwivedi, A.; Jain, M. K. Fly Ash - Waste Management and Overview : A Review.

Recent Res. Sci. Technol. 2014, 6 (1), 30-35. https://doi.org/10.1111/j.1523-

1739.2008.00978.x.

(9) Querol, X.; Plana, F.; Alastuey, A.; Lbpez-Soler, A. Synthesis of Na-Zeolites from Fly Ash. Fuel 1997, 76 (8), 236100188-3. https://doi.org/10.1016/S0016-2361(96)00188-3.

(10) Álvarez-Ayuso, E.; García-Sánchez, A.; Querol, X. Purification of Metal Electroplating 
503

504

505

506

507

508

509

510

511

512

513

514

515

516

517

518

519

520

521

https://doi.org/10.1016/j.watres.2003.08.009.

(11) Moreno, N.; Querol, X.; Andrés, J. M.; Stanton, K.; Towler, M.; Nugteren, H.; JanssenJurkovicová, M.; Jones, R. Physico-Chemical Characteristics of European Pulverized Coal Combustion Fly Ashes. Fuel 2005, 84 (11), 1351-1363.

(12) Ruhl, L.; Vengosh, A.; Dwyer, G. S.; Hsu-Kim, H.; Deonarine, A. Environmental Impacts of the Coal Ash Spill in Kingston, Tennessee: An 18-Month Survey. Environ. Sci. Technol. 2010, 44 (24), 9272-9278.

(13) Catalano, J. G.; Huhmann, B. L.; Luo, Y.; Mitnick, E. H.; Slavney, A.; Giammar, D. E. Metal Release and Speciation Changes during Wet Aging of Coal Fly Ashes. Environ. Sci. Technol. 2012, 46 (21), 11804-11812.

(14) Yang, Y.; Colman, B. P.; Bernhardt, E. S.; Hochella, M. F. Importance of a Nanoscience Approach in the Understanding of Major Aqueous Contamination Scenarios: Case Study from a Recent Coal Ash Spill. Environ. Sci. Technol. 2015, 49 (6), 3375-3382.

(15) Harkness, J. S.; Sulkin, B.; Vengosh, A. Evidence for Coal Ash Ponds Leaking in the Southeastern United States. Environ. Sci. Technol. 2016, 50 (12), 6583-6592.

(16) Brandt, J. E.; Simonin, M.; Di Giulio, R. T.; Bernhardt, E. S. Beyond Selenium: Coal Combustion Residuals Lead to Multielement Enrichment in Receiving Lake Food Webs. Environ. Sci. Technol. 2019, 53 (8), 4119-4127.

(17) Höller, H.; Wirsching, U. Zeolite Formation from Fly Ash. Fortschritte der Mineral. 1985, $63(1), 21-43$. 
(18) Lin, C. F.; Hsi, H. C. Resource Recoveiy of Waste Fly Ash: Synthesis of Zeolite-like Materials. Environ. Sci. Technol. 1995, 29 (4), 1109-1117. https://doi.org/10.1021/es00004a033.

(19) Querol, X.; Moreno, N.; Umaa, J. C.; Alastuey, A.; Hernández, E.; López-Soler, A.; Plana, F. Synthesis of Zeolites from Coal Fly Ash: An Overview. Int. J. Coal Geol. 2002, 47 (1-4), 413-423. https://doi.org/10.1088/1757-899X/230/1/012044.

(20) Murayama, N.; Yamamoto, H.; Shibata, J. Mechanism of Zeolite Synthesis from Coal Fly Ash by Alkali Hydrothermal Reaction. Int. J. Miner. Process. 2002, 64 (1), 1-17. https://doi.org/10.1016/S0301-7516(01)00046-1.

(21) Querol, X.; Alastuey, A.; López-Soler, A.; Plana, F.; Andrés, J. M.; Juan, R.; Ferrer, P.; Ruiz, C. R. A Fast Method for Recycling Fly Ash: Microwave-Assisted Zeolite Synthesis. Environ. Sci. Technol. 1997, 31 (9), 2527-2533. https://doi.org/10.1021/es960937t.

(22) Steenbruggen, G.; Hollman, G. G. The Synthesis of Zeolites from Fly Ash and the Properties of the Zeolite Products. J. Geochemical Explor. 1998, 62 (1-3), 305-309. https://doi.org/10.1016/S0375-6742(97)00066-6.

(23) Inglezakis, V. J.; Grigoropoulou, H. P. Applicability of Simplified Models for the Estimation of Ion Exchange Diffusion Coefficients in Zeolites. J. Colloid Interface Sci. 2001, 234 (2), 434-441. https://doi.org/10.1006/jcis.2000.7304.

(24) Singer, A.; Berkgaut, V. Cation Exchange Properties of Hydrothermally Treated Coal Fly Ash. Environ. Sci. Technol. 1995, 29 (7), 1748-1753. 
544

545

546

547

548

549

550

551

552

553

554

555

556

557

558

559

560

561

562

563

(25) Moreno, N.; Querol, X.; Ayora, C.; Pereira, C. F.; Janssen-Jurkovicová, M. Utilization of Zeolites Synthesized from Coal Fly Ash for the Purification of Acid Mine Waters.

Environ. Sci. Technol. 2001, 35 (17), 3526-3534. https://doi.org/10.1021/es0002924.

(26) Lee, K.-M.; Jo, Y.-M. Synthesis of Zeolite from Waste Fly Ash for Adsorption of CO 2. J. Mater. Cycles Waste Manag. 2010, 12 (3), 212-219.

(27) Chang, E. E.; Chen, C. H.; Chen, Y. H.; Pan, S. Y.; Chiang, P. C. Performance Evaluation for Carbonation of Steel-Making Slags in a Slurry Reactor. J. Hazard. Mater. 2011, 186 (1), 558-564. https://doi.org/10.1016/j.jhazmat.2010.11.038.

(28) Tamilselvi Dananjayan, R. R.; Kandasamy, P.; Andimuthu, R. Direct Mineral Carbonation of Coal Fly Ash for CO2sequestration. J. Clean. Prod. 2016. https://doi.org/10.1016/j.jclepro.2015.05.145.

(29) Ecke, H. Sequestration of Metals in Carbonated Municipal Solid Waste Incineration (MSWI) Fly Ash. Waste Manag. 2003, 23 (7), 631-640. https://doi.org/10.1016/S0956053X(03)00095-3.

(30) Montes-Hernandez, G.; Pérez-López, R.; Renard, F.; Nieto, J. M.; Charlet, L. Mineral Sequestration of CO2 by Aqueous Carbonation of Coal Combustion Fly-Ash. J. Hazard. Mater. 2009, 161 (2-3), 1347-1354. https://doi.org/10.1016/j.jhazmat.2008.04.104.

(31) Thomas, M. D. A.; Matthews, J. D. Carbonation of Fly Ash Concrete. Mag. Concr. Res. 1992, 44 (160), 217-228. https://doi.org/10.1680/macr.1992.44.160.217.

(32) Wang, L.; Jin, Y.; Nie, Y. Investigation of Accelerated and Natural Carbonation of MSWI Fly Ash with a High Content of Ca. J. Hazard. Mater. 2010, 174 (1-3), 334-343. 
https://doi.org/10.1016/j.jhazmat.2009.09.055.

566 (33) Back, M.; Kuehn, M.; Stanjek, H.; Peiffer, S. Reactivity of Alkaline Lignite Fly Ashes towards CO2 in Water. Environ. Sci. Technol. 2008, 42 (12), 4520-4526.

568 (34) Evangelos Georgakopoulos (Cranfield University, UK), Rafael M. Santos ( Sheridan 569 Appl. Crystallogr. 1969, 2 (2), 65-71. https://doi.org/10.1107/S0021889869006558. 
586

587

588

589

590

591

592

593

594

595

596

597

598

599

600

601

602

603

604

605

606

Content Analysis. J. Appl. Crystallogr. 2001, 34 (2), 196-202.

https://doi.org/10.1107/S0021889801002485.

(41) Cliff, G.; Lorimer, G. The Quantitative Analysis of Thin Specimens. J. Microsc. 1975, 103 (2), 203-207.

(42) Zeng, R.; Umana, J. C.; Querol, X.; Lopez-Soler, A.; Plana, F.; Zhuang, X. Zeolite Synthesis from a High Si-Al Fly Ash from East China. J. Chem. Technol. Biotechnol. 2002, 77 (3), 267-273. https://doi.org/10.1002/jctb.598.

(43) Monasterio-Guillot, L.; Di Lorenzo, F.; Ruiz-Agudo, E.; Rodriguez-Navarro, C. Reaction of Pseudowollastonite with Carbonate-Bearing Fluids: Implications for CO2 Mineral Sequestration. Chem. Geol. 2019, 524, 158-173.

https://doi.org/10.1016/j.chemgeo.2019.06.011.

(44) Thiery, M.; Villain, G.; Dangla, P.; Platret, G. Investigation of the Carbonation Front Shape on Cementitious Materials: Effects of the Chemical Kinetics. 2007. https://doi.org/10.1016/j.cemconres.2007.04.002.

(45) Nyambura, M. G.; Mugera, G. W.; Felicia, L.; Gathura, N. P. Carbonation of Brine Impacted Fractionated Coal Fly Ash: Implications for CO 2 Sequestration.

(46) Fernández Bertos, M.; Simons, S. J. R.; Hills, C. D.; Carey, P. J. A Review of Accelerated Carbonation Technology in the Treatment of Cement-Based Materials and Sequestration of CO 2. J. Hazard. Mater. 2004, 112, 193-205.

https://doi.org/10.1016/j.jhazmat.2004.04.019. 
607 (47) Duxson, P.; Provis, J. L. Designing Precursors for Geopolymer Cements. J. Am. Ceram.

608

609

610

611

612

613

614

615

616

617

618

619

620

621

622

623

624

625

626

Soc. 2008, 91 (12), 3864-3869.

(48) Vassilev, S. V; Menendez, R.; Alvarez, D.; Diaz-Somoano, M.; Martinez-Tarazona, M.

R. Phase-Mineral and Chemical Composition of Coal Fly Ashes as a Basis for Their

Multicomponent Utilization. 1. Characterization of Feed Coals and Fly Ashes $\hat{\gamma}^{-}$Fuel

2003, 82 (14), 1793-1811.

(49) Farmer, V. C. Orthosilicates, Pyrosilicates, and Other Finite-Chain Silicates. In The

Infrared Spectra of Minerals; Farmer, V. C., Ed.; Mineralogical Society of Great Britain and Ireland, 1974.

(50) Mozgawa, W.; Mozgawa, W.; Handke, M.; Jastrze, W. Vibrational Spectra of

Aluminosilicate Structural Clusters Synthesis and Structural Studies of Zeolite

Membranes on Geopolimeric Supports View Project Vibrational Spectra of

Aluminosilicate Structural Clusters. Artic. J. Mol. Struct. 2004.

https://doi.org/10.1016/j.molstruc.2004.01.059.

(51) Fernández-Pereira, C.; Galiano, Y. L.; Rodríguez-Piñero, M. A.; Vale, J.; Querol, X.

Utilisation of Zeolitised Coal Fly Ash as Immobilising Agent of a Metallurgical Waste. $J$.

Chem. Technol. Biotechnol. Int. Res. Process. Environ. Clean Technol. 2002, 77 (3),

305-310.

(52) Sánchez-Hernández, R.; López-Delgado, A.; Padilla, I.; Galindo, R.; López-Andrés, S.

One-Step Synthesis of NaP1, SOD and ANA from a Hazardous Aluminum Solid Waste.

Microporous Mesoporous Mater. 2016, 226, 267-277. 
628

629

630

631

632

633

634

635

636

637

638

639

640

641

642

643

644

645

646

647

648

(53) Kosanovic, C.; Subotic, B.; Smit, I.; Cizmek, A.; Stubicar, M.; Tonejc, A. Study of

Structural Transformations in Potassium-Exchanged Zeolite A Induced by Thermal and

Mechanochemical Treatments. J. Mater. Sci. 1997, 32 (1), 73-78.

(54) Fahlke, B.; Starke, P.; Seefeld, V.; Wieker, W.; Wendlandt, K.-P. On the Intermediates in Zeolite Y Synthesis. Zeolites 1987, 7 (3), 209-213.

(55) Shigemoto, N.; Sugiyama, S.; Hayashi, H.; Miyaura, K. Characterization of Na-X, Na-A, and Coal Fly Ash Zeolites and Their Amorphous Precursors by IR, MAS NMR and XPS.

J. Mater. Sci. 1995, 30 (22), 5777-5783.

(56) Morsli, A.; Driole, M.-F.; Cacciaguerra, T.; Arletti, R.; Chiche, B.; Hamidi, F.;

Bengueddach, A.; Quignard, F.; Di Renzo, F. Microporosity of the Amorphous

Aluminosilicate Precursors of Zeolites: The Case of the Gels of Synthesis of Mordenite.

Microporous mesoporous Mater. 2007, 104 (1-3), 209-216.

(57) rodriguez-Navarro, C.; ruiz-agudo, eNCarNaCioN; luque, aNa; rodriguez-Navarro, alejaNdro B.; ortega-Huertas, M. Thermal Decomposition of Calcite: Mechanisms of Formation and Textural Evolution of CaO Nanocrystals. Am. Mineral. 2009, 94, 578593. https://doi.org/10.2138/am.2009.3021.

(58) Demir, F.; Dönmez, B.; Okur, H.; Sevim, F. Calcination Kinetic of Magnesite from Thermogravimetric Data. Chem. Eng. Res. Des. 2003, 81 (6), 618-622.

(59) de Souza, F.; Bragança, S. R. Thermogravimetric Analysis of Limestones with Different Contents of $\mathrm{MgO}$ and Microstructural Characterization in Oxy-Combustion. Thermochim. Acta 2013, 561, 19-25. 
649 (60) Goldsmith, J. R.; Graf, D. L.; Chodos, A. A.; Joensuu, O. I.; McVicker, L. D. Relation

650

651

652

653

654

655

656

657

658

659

660

661

662

663

664

665

666

667

668

669

between Lattice Constants and Composition of Ca-Mg Carbonates. Am. Mineral. J. Earth

Planet. Mater. 1958, 43 (1-2), 84-101.

(61) Mavromatis, V.; Gautier, Q.; Bosc, O.; Schott, J. Kinetics of Mg Partition and Mg Stable Isotope Fractionation during Its Incorporation in Calcite. Geochim. Cosmochim. Acta 2013, 114, 188-203.

(62) Monasterio-Guillot, L.; Di Lorenzo, F.; Ruiz-Agudo, E.; Rodriguez-Navarro, C. Reaction of Pseudowollastonite with Carbonate-Bearing Fluids: Implications for $\mathrm{CO}<\inf >2</ \operatorname{Inf}>$ Mineral Sequestration. Chem. Geol. 2019, 524. https://doi.org/10.1016/j.chemgeo.2019.06.011.

(63) Casey, W. H.; Westrich, H. R.; Massis, T.; Banfield, J. F.; Arnold, G. W. The Surface of Labradorite Feldspar after Acid Hydrolysis. Chem. Geol. 1989, 78 (3-4), 205-218. https://doi.org/10.1016/0009-2541(89)90058-2.

(64) Hellmann, R.; Penisson, J. M.; Hervig, R. L.; Thomassin, J. H.; Abrioux, M. F. An EFTEM/HRTEM High-Resolution Study of the near Surface of Labradorite Feldspar Altered at Acid PH: Evidence for Interfacial Dissolution-Reprecipitation. Phys. Chem. Miner. 2003, 30 (4), 192-197. https://doi.org/10.1007/s00269-003-0308-4.

(65) Ruiz-Agudo, E.; King, H. E.; Patiño-López, L. D.; Putnis, C. V; Geisler, T.; RodriguezNavarro, C.; Putnis, A. Control of Silicate Weathering by Interface-Coupled DissolutionPrecipitation Processes at the Mineral-Solution Interface. Geol. 2016, 44 (7), 1-4. https://doi.org/10.1130/G37856.1. 
670

671

672

673

674

675

676

677

678

679

680

681

682

683

684

685

686

687

688

689

690

69

70

(66) Ruiz-Agudo, E.; Putnis, C. V.; Rodriguez-Navarro, C.; Putnis, A. Mechanism of Leached Layer Formation during Chemical Weathering of Silicate Minerals. Geology 2012, 40 (10), 947-950. https://doi.org/10.1130/G33339.1.

(67) Catalfamo, P.; Corigliano, F.; Primerano, P.; Di Pasquale, S. Study of the PreCrystallization Stage of Hydrothermally Treated Amorphous Aluminosilicates through the Composition of the Aqueous Phase. J. Chem. Soc. Faraday Trans. 1993, 89 (1), 171175.

(68) Itani, L.; Liu, Y.; Zhang, W.; Bozhilov, K. N.; Delmotte, L.; Valtchev, V. Investigation of the Physicochemical Changes Preceding Zeolite Nucleation in a Sodium-Rich Aluminosilicate Gel. J. Am. Chem. Soc. 2009, 131 (29), 10127-10139.

(69) Yan, F.; Jiang, J.; Li, K.; Tian, S.; Zhao, M.; Chen, X. Performance of Coal Fly Ash Stabilized, CaO-Based Sorbents under Different Carbonation-Calcination Conditions. 2015. https://doi.org/10.1021/acssuschemeng.5b00355.

(70) Thommes, M.; Kaneko, K.; Neimark, A. V; Olivier, J. P.; Rodriguez-Reinoso, F.; Rouquerol, J.; Sing, K. S. W. Physisorption of Gases, with Special Reference to the Evaluation of Surface Area and Pore Size Distribution (IUPAC Technical Report). Pure Appl. Chem. 2015, 87 (9-10), 1051-1069.

(71) Parkhurst, D. L.; Appelo, C. A. J. USER'S GUIDE TO PHREEQC (VERSION 2)-A COMPUTER PROGRAM FOR SPECIATION, BATCH-REACTION, ONEDIMENSIONAL TRANSPORT, AND INVERSE GEOCHEMICAL CALCULATIONS.

(72) Shigemoto, N.; Hayashi, H.; Miyaura, K. Selective Formation of Na-X Zeolite from Coal 

Sci. 1993, 28 (17), 4781-4786. https://doi.org/10.1007/BF00414272.

693

694

695

696

697

698

699

700

701

702

703

704

705

706

707

708

709

(73) Hollman, G. G.; Steenbruggen, G.; Janssen-Jurkovičová, M. Two-Step Process for the Synthesis of Zeolites from Coal Fly Ash. Fuel 1999, 78 (10), 1225-1230.

https://doi.org/10.1016/S0016-2361(99)00030-7.

(74) Du Plessis, P. W.; Ojumu, T. V.; Petrik, L. F. Waste Minimization Protocols for the Process of Synthesizing Zeolites from South African Coal Fly Ash. Materials (Basel). 2013, 6 (5), 1688-1703. https://doi.org/10.3390/ma6051688.

(75) Rodríguez-Navarro, C.; Ruiz-Agudo, E.; Harris, J.; Wolf, S. E. Nonclassical

Crystallization in Vivo et in Vitro (II): Nanogranular Features in Biomimetic Minerals Disclose a General Colloid-Mediated Crystal Growth Mechanism. 2016. https://doi.org/10.1016/j.jsb.2016.09.005.

(76) Henry, J.; Towler, M. R.; Stanton, K. T.; Querol, X.; Moreno, N. Characterisation of the Glass Fraction of a Selection of European Coal Fly Ashes. J. Chem. Technol. Biotechnol. 2004, 79 (5), 540-546. https://doi.org/10.1002/jctb.1023.

(77) Izquierdo, M.; Querol, X. Leaching Behaviour of Elements from Coal Combustion Fly Ash: An Overview. Int. J. Coal Geol. 2012, 94, 54-66. https://doi.org/10.1016/j.coal.2011.10.006.

(78) Spears, D. A.; Martinez-Tarrazona, M. R. Trace Elements in Combustion Residues from a UK Power Station. Fuel 2004, 83 (17-18), 2265-2270.

(79) Terzano, R.; Spagnuolo, M.; Medici, L.; Vekemans, B.; Vincze, L.; Janssens, K.; 
Ruggiero, P. Copper Stabilization by Zeolite Synthesis in Polluted Soils Treated with

Coal Fly Ash. Environ. Sci. Technol. 2005, 39 (16), 6280-6287. https://doi.org/10.1021/es050079d.

715

716

717

718

719

720

721

722

723

724

725 726

(80) Gupta, V. K.; Carrott, P. J. M.; Ribeiro Carrott, M. M. L.; Suhas. Low-Cost Adsorbents:

Growing Approach to Wastewater Treatment-a Review. Crit. Rev. Environ. Sci.

Technol. 2009, 39 (10), 783-842.

(81) Ukwattage, N. L.; Ranjith, P. G.; Yellishetty, M.; Bui, H. H.; Xu, T. A Laboratory-Scale Study of the Aqueous Mineral Carbonation of Coal Fly Ash for CO2 Sequestration. $J$. Clean. Prod. 2015, 103, 665-674.

(82) Sun, Y.; Parikh, V.; Zhang, L. Sequestration of Carbon Dioxide by Indirect Mineralization Using Victorian Brown Coal Fly Ash. J. Hazard. Mater. 2012, 209-210, 458-466. https://doi.org/10.1016/j.jhazmat.2012.01.053.

(83) He, L.; Yu, D.; Lv, W.; Wu, J.; Xu, M. A Novel Method for CO 2 Sequestration via Indirect Carbonation of Coal Fly Ash. 2013. https://doi.org/10.1021/ie4023644. 